\title{
Discourse and power in the Gospel according to Mark: Strategies of exclusion
}

(Dedicated to the memory of John McCallum)

Johannes A. Smit

Department of Biblical Literature

University of Durban-Westville

DURBAN

\begin{abstract}
In this article it is angued that the materiality of religious discourse necessitates a description of its strategies of power and control. Since Christian religious discourse reactivates the discourses of canonical writings, the description of the materiality of the discursive practices of the canonical writings themselves is imperative. Focusing on the strategics of exclusion, Foucault's archaeological model of the description of discourse is used as a framework for delineating some strategies of the Markan discourse.
\end{abstract}

The analysis of the archive ... involves a privileged region: at once close to us, and different from our present existence, it is the border of time that surrounds our presence, which overhangs it, and which indicates it in its otherness; it is that which, outside ourselves, delimits us (Foucault, 1972:130).

\section{INTRODUCTION}

Since religious discourse plays an important role in history, it is imperative that its power of control and rarefaction be described. As a preliminary attempt, this paper deals with the discourse and power in a canonical gospel. The reason for this approach is that the canonical writings of the Bible which are read, preached from and used to legitimate a great variety of social and political practices in society, are used uncritically with regard to the material qualities of their discourses. In this preliminary attempt, Michel Foucault's essay "The discourse on language" (1972:215ff) is used as model for the description of discourse and power in Mark. At this stage of the research, no attempt will be made to present a comprehensive archaeological or genealogical description of the discourse in Mark. However, some definitions of terminology used are provided (cf. section 2 ) and a few exploratory arguments will be offered (cf. section 3 ). ${ }^{1}$

1 The definitions in themselves do not explore the full complexity and multiplicity of Foucault's own usc of the terminology. They are also not provided as an indicator that I use stable 


\section{TERMINOLOGY}

- Archive/Archaeology: According to Foucault (1972:130), the archive is to be defined at a particular level which is to be located between the langue (which defines the system of constructing possible sentences) and the canonic corpus in which the multiplicity of statements or the words which are spoken are passively collected. The archaeology of knowledge studies the archive, i.e. the level at which the "practice that causes a multiplicity of statements to emerge as so many things to be dealt with and manipulated". It studies the "rules of practice that enable statements both to survive and to undergo regular modification". It is "the general system of the formation and the transformation of statements" (Foucault, 1972:130).

- Discourse: Whereas Mikhail Bakhtin relates discourse to parole, Foucault $(1972: 37)$ defines it in terms of "large groups of (dispersed - my insertion) statements" which form a particular discipline, e.g. medicine, economics or grammar. Since the unity of discourse can not be described in terms of a "... geographically well-defined field of objects", a "... normative type of statement", a "well-defined alphabet of notions" nor "the permanence of a thematic", discourse has to be described in terms of its rule-governed "system of dispersions". Within a particular discipline such as that of Mark, the rule-governed system of dispersions can be defined in terms of their discursive formation. This definition is done in terms of the regularity, i.e. the order, correlations, positionings and functionings and transformations, which exist between objects, types of statement, concepts or thematic choices within a particular discourse/ discipline (cf. Foucault, 1972:38).

* Power: Foucault (1980b) argues that it is especially the rules of formation of discourses/disciplines which are linked to a particular kind of social power. Discourses do not only exhibit immanent and external principles of regularity. They are bound by regulations enforced through social practices of appropriation, control and policing. As far as discourse excludes, limits and prohibits, it is a negative political commodity. In so far as discourse constructs programmes for the formation of a social reality aimed at intervention and a functioning totality, the power of discourse has a more positive and productive power (Foucault, 1980a:119).

Foucauldian definitions. The only valid tribute to thought such as Foucault's is precisely to use it, to deform it, to make it groan and protest. 
- Discursive practice: The exercise of power by discourse can be described as a practice because it prohibits and/or establishes certain relationships between diverse, heterogenous elements. Discourse controls and manipulates not only the conditions of social relations, but also the material realities in the social body.

* Strategies: The purpose of the analysis of strategies operative in discourse as well as on the periphery of discourse aims at the description of the manner in which they fail to bring about the intended effects. In terms of the Markan discourse, it is argued in this article that the strategies of exclusion - which aimed at the inclusion of the marginalized people in society in the community living under the rule of God' - failed precisely because of the materiality of its strategies of exclusion. This paradox is evident in the way in which the Christian state persecuted the Jews through the centuries as well as how it excluded Christians in South Africa from the life 'under the rule of God' on the basis of ethnic difference.

\section{DISCOURSE AND POWER}

With regard to what discourse is and how it should be described, Foucault (1972:216) suggests as hypothesis that "in every society the production of discourse is at once controlled, selected, organised and redistributed according to a certain number of procedures whose role is to avert its powers and its dangers, to cope with chance events, to evade its ponderous, awesome materiality". This definition calls forth three observations.

\subsection{Discourse is society specific}

Every discourse is specific to the society in which it is produced. This observation must not be regarded as a procedure in which Foucault endeavours to uphold the hermeneutical presupposition that every sign, expression or text is situation or context specific. On the contrary, Foucault reacts against hermeneutics, especially in so far as hermeneutics endeavours to uncover the context or horizon and hidden meanings of a particular text. This statement must rather be examined in terms of the strategies of power and control operative in discourse in its interaction with the totality of discursive practices in social situations. 'Totality' must not be regarded as either an indication that Foucault holds that it is possible to describe one particular discourse in terms of all theoretical discourses which exist in a society, but as an indication that the rules and strategies of one particular discourse form part of multiple fragments of discourse in a 
society's unspoken archive. ${ }^{2}$ An important presupposition which also has to be taken into consideration in the description of the history of discourse and power is that Foucault goes one step further than Husserl by not only bracketing the signified but also the signifier of a sign, expression or text, in order to effect a double decontextualisation. The ultimate aim of this double decontextualisation is to study the material realities of discourse as they are suppressed in discourse or awakened from their slumber in passing from society to society. ${ }^{3}$ As far as the historian is concerned, this double decontextualisation also enables one to resist (or reject) any relation of obligation between history and the historian (Dreyfuss \& Rabinow, 1982:49ff).

\subsection{The centripetal elements of discourse formation}

The second observation pertains to the fact that "discourse is at once controlled, selected, organised and redistributed" (vide first paragraph of section 3, p. 13). It seems to me that this statement by Foucault emphasises the centripetal elements of discourse formation. The powers and rules of control which function in the production of a particular discourse are powers and rules which serve as internal rules or principles of rarefaction in discourse. In other words, they operate as rules of classification, ordering and distribution which aim at the establishment of a homogenous discourse for the discipline or social group. But Foucault goes further. These rules of control or rarefaction are also imposed on the individuals who employ the particular discourse - i.e. a rarefaction among speaking and receiving (or listening/reading) subjects. Their function is to deny access to everyone else. As such, these internal rules function as principles of rarefaction which are necessary for authorizing and guaranteeing the homogeneity of discourse, not only in its production, but also in its redistribution.

2 It is impossible to describe the 'totality' of fragments from which the Markan discourse emerges within the confincs of this article. That is why I rely - especially in section 4 - on the work of other scholars who have studied such 'fragments'.

3 I am using the concept of society here not only in the strict sense of how strategies are used by different discourses or disciplines within the same epoch, but also how different societics as epochs use and reawaken strategics of disciplines in previous cpochs within their own, albeit in a distorted sense. 


\subsection{Discourse formation takes place according to certain procedures of exclusion}

The third observation concerns the statement that the production of discourse takes place "according to a certain number of procedures whose role is to avert its powers and its dangers, to cope with chance events, to evade its ponderous, awesome materiality" (vide first paragraph of section 3, p. 13). It appears as if this statement is aimed at the rules or systems of exclusion which function on the exterior of discourse according to the dicta of power and desire. In the production of discourse - which serves the desired political aspirations or defensive strategies of a particular social group certain strategies of exclusion and prohibition are generated in order to demarcate the boundaries which set the discourse (and by implication the socio-political group participating in this discourse) off from other discursive practices (and social groups). As such, the language with which strategies of exclusion and prohibition are prescribed does not only function as the medium but also as the object of desire (Foucault, 1972:216). The language of the discourse is not merely the speechifying of conflicts and systems of control of a particular social group, but also the domain or space in which the material realities of the group are defined. Discourse, therefore can be regarded as the social location in which desired (and undesired) behaviour - which results from discourse as a discursive practice - is defined contra the behaviour propounded by opposing discourses. ${ }^{4}$

In order to describe the Markan discourse, my first objective is to identify some religiopolitical and socio-economic conventions operative in the society within which it came into being, i.e. the dominant discourse of Roman domination. These conventions are ingrained in the very fabric of the Markan discourse. Second, I describe the Markan discourse in terms of its external rules of exclusion. ${ }^{5}$ Since it is the main objective of a Foucauldian historical description of discourse to bring out the discontinuity between discourses, I make a few observations with regard to the discontinuity between the discursive practices of Mark and the discourses of Christian apartheid South Africa.

$4 \quad$ Mack (1988:207) rightfully states that Mark's casting of the miracles and the pronouncements of Jesus within the form of conflict is not at all innocent. In the literary form of conflict discourses, Jesus' pronouncements do not lead to innocent education and "enlightenment, but to violence, blame, and judgment".

5 I leave the discussion of the internal rules of rarefaction operative in Mark and the internal rules of rarefaction which are imposed on individuals by this text for another article. 


\section{SOCIETY IN THE MARKAN DISCOURSE 6}

Contrary to contemporary Western society, religion in the first century Mediterranean world was not practised in a vacuum. The practice of religion was not separated from public and political life. ${ }^{7}$ It was an integral part of politics and economics ${ }^{8}$ (cf. Bickerman, 1988:257ff; Borg, 1984:27ff; Fears, 1980:98ff; Maccoby, 1973:72ff and Myers, 1990:39ff). Temples were the hub of societies, not only because the ethnically 9 determined religious rites were practised there, but also because the economy respons-

6 It is not my aim here to supply a hermeneutically required context or horizon for what follows. Since space does not allow a comprehensive discussion of the variety of discourses in first century Mediterranean society, I merely provide an overview of some of the basic practices which played a role in these discourses.

7 I believe that this statement can be generalized for the first century Mediterranean world. At this stage into the research of this phenomenon, I only give one example. On the occasion that Herod was declared king by the senate in Rome, we read:

"And when the senate was separated/dissolved, Antony and Caesar (Augustus) went ou with Herod between them; while the consul and the rest of the magistrates went before them, in order to offer sacrifices, and to lay the decree in the capitol. Ant ony also made a feast for Herod on the first day of his reign" (Josephus, War.I.xiv.4)

Johnson (1986:29) states in this regard:

"From the first genuflection before Alexander the Great to the deification of Claudius, the imperial cult was a specifically political form of religious manipulation, never pretending to express the longing of human hearts."

8 Cf. the business which was generated by the making of silver shrines to the honour of Artemis (Ac. 19:24ff). Haenchen (1977:548) states in this regard that these "silver temples" were used as pilgrimage souvenirs, gifts of worship and devotion and amulcts. Such practices with the resultant incentives it provided for business were widespread in the first century Mediteranean world.

9 Freyne (1989:189f) states that first century Christians were not an ethnic group with a traditional ethnic religion like the Jews. Under certain conditions, the Jews were allowed to worship their own God. This was regarded as a "concession to an ancient people and for ethnic reasons" (Freyne, 1989:190). According to Josephus (Ant.XI.viii:4-6), Alexander granted the Jews permission "to enjoy the laws of their forefathers". This permission was also granted to Jews in Babylon, Media and even to those serving in his army. Despite the fact that Alexander propagated the universalizing of Greek religion and the resultant syncretism that it brought about (cf. Johnson, 1986:25), the existence and practicc of some of these traditional religions (except for Judaism) continued well into the fourth century C.E. Most probably, one of the reasons for this phenomenon, is the fact that many of the traditional (Aramaic ethnic) religions were linked to particular holy places. Places where new revelations of the same traditional religion took place were also added to the traditional localities on a continuous basis (cf. Hoftijzer, 1968:22). 
ible for all sacrificial requirements (e.g. the buying and selling of animals and birds for sacrifice) as well as moneychangeing, took place there. Since the sacrificial requirements provided very important economic incentives - i.e. apart from the production of food, drink and clothing - temples functioned as centres of trade and industry. They also provided a religiously sanctioned channel for the collection of taxes. In addition, surplus agricultural produce was stored there for redistribution in years of drought and famine. Needless to say, this system was thoroughly exploited by corrupt officials for economic gain (cf. Myers, 1990:47ff; Biale, 1986:21). It is understandable, therefore, that the political collaboration of temples was a very important aspect of the political domination and imperial control in the Roman Empire. ${ }^{10}$

The other side of the coin, obviously, is that the local populations would find themselves in an existential double-bind: on the one hand, they resisted not only the Romans, but also the religio-political officials who collaborated with the Imperium; on the other, since temples formed the hub of religious, political, economic and educational life, they were coerced not only to collaborate with the oppressors but also to be collaborators in their own oppression through their involvement in the life and culture sustaining activities centred in the temple. Since local populations experienced these practices as oppressive, a great number of discursive practices developed from below and more often than not, resulted in outbreaks of violent, revolutionary uprisings (the Jewish political messiahs and Zealots) and non-violent resistance (the Jewish apocalyptic messiahs and communities - e.g. Qumran) (cf. Borg, 1984:36ff; Horsley \& Hanson, 1985; Myers, 1990:82ff). Apart from the co-operation of the temple élite, ${ }^{11}$ the other main strategies which the Roman oppressors followed in their subjection of conquered people(s) included a "network of personal alliances with the ruling classes throughout the empire" (Fears, 1980:98f), a "political theology of victory" (Fears, 1980:99) and the use of apologists and propagandists propagating a pax which only served the approximately 5\% of the Mediterranean élite (cf. Wengst, 1987:7ff). Also included were building projects which resulted in heavy taxation and brutal repression

10 The importance of temples as instruments of political control is evident from the fact that in addition to the building of the temple at Jerusalem which Herod the Great initiated, he also built two temples, one in honour of Caesar Augustus ncar Paneas (Josephus, Ant.XV.X.3 and War.IV.i.1) and one at Samaria (Joscphus, Ant.XV.xiii.5). These three temples were obviously used as part of a stratcgy of manipulation and control of all the people under his jurisdiction. The Jerusalem temple was used to control the Jewish population (both in Judea and Galilee), the temple at Samaria, to control the Samaritans (in central Palcstine) and the temple at Paneas to control the people to the north of Galilee.

11 Horslcy and Hanson (1985:62) point out that "the high pricstly families which Herod brought in and which monopolized the chicf pricstly offices right up to the Jewish revolt were, some of them, not cuen Palestinian Jewish families, but powerful families from the diaspora". 
(especially by Herod the Great - cf. Ferguson, 1987:329; Biale, 1986:21), the Hellenization of cultures - e.g. through naked sports in stadiums and naked physical training in gymnasia (since the time of the Seleucids - cf. Ferguson, 1987:322) ${ }^{12}-$, the farming out of taxes, ${ }^{13}$ the Emperor cult ${ }^{14}$ and more directly the presence and activities of policing and suppression by soldiers. To this must be added the exploitation of the peasant population by corrupt procurators and prefects. ${ }^{15}$

12 Ferguson (1987:322) states in this regard that "some (Jewish) youths underwent an operation to hide their circumcision so as not to be ridiculed by the Greeks".

13 Borg (1984:32f) describes the two systems of taxation to which the Jewish people were submitted - i.e. the taxes of the temple, and those required by the Imperium. Jews from the diaspora who could not pay with agricultural produce, paid with moncy which was changed into local currency at the temple. The annual temple tax which the Jewish peasant had to pay comprised the 'temple tax' of about one day's labour, the first fruits offering of $1-3 \%$ of the produce and $10 \%$ of the produce for the support of the priests and the levites at the temple. To this must be added the 'second tithe' of $10 \%$ of the produce in the first, second, fourth and fifth years of the seven year cycle and the 'poor man's tithe' also of $10 \%$ in the third and fourth years. This adds up to a little more than $20 \%$ of the annual produce. According to Torah, this had to be paid to the temple. To this must be added the taxes of the Romans. This comprised crop and land taxes, a poll (or tribute) tax, customs and tolls. A conservative calculation is that it cost the Jewish peasant about another $25 \%$ of his produce. To this must also be added the fact that the farming out of taxes was hierarchically structured. This implied that a 'ruler' like Herod the Great would purchase the right to administer and collect taxes in a certain area with revenue money. He would in turn sell the right to collect taxes and toll to other people who in turn would sell this right to others, until we come to the person who collected it from the peasants. A certain amount was taken by the tax or toll collector himself to support his own (often excessive) lifestyle. The rest was paid to the person 'above' from which he would take a part as his income (usually excessive) and would enable this person to meet his commitments to the one above him, and so forth.

14 The celebration of impcrial anniversarics, i.e. birthdays, the beginning of an emperor's rule, victories, etc. "provided a number of opportunities in each year for public ovations, proclamations, and pageants celebrating the virtues of the Emperor" (Fears, 1980:102). In addition to this, the different religious cults had to bring daily sacrifices for the Emperor. These sacrifices served as a token of obedient allegiance to Roman rule. This activity constituted - especially to the Jews who also had to present them in the temple at Jerusalem at least once a day - a grave abomination.

15 Borg (1984:29) states that it was especially after 6 C.E. that the exploitation of prefects escalated in Palestine. After the demise of the rule of the house of Herod, Roman control was in the hands of "second-rank and often second-rate Roman colonial administrators, sometimes, simply incompetent, sometimes corrupt, sometimes deliberately provocative of Jewish sensitivities". Biale (1986:21) states in this regard that "Herod left no legitimate and recognized leadership behind. The Romans moved into the void and established the direct rule of Judea under procurators*. 
It was in this world order that Christianity appeared on the scene. Since only traditional ethnic specific religions qualified for recognition under Roman Law, Christianity, which could claim neither traditional nor ethnic basis, was regarded as a seditious movement and consequently persecuted sporadically (cf. Freyne, 1989:189ff). The main reasons for this were that Christians could not be coerced through a temple hierarchy nor through traditional leaders nor were they clearly defined in terms of ethnicity. As a religious 'philosophy', the discursive practice of Christianity not only disregarded all strategies of imperial control (cf. above), but also practised a radica egalitarian society in which people served each other and did not 'lord it over others' (Mk. 10:42-44).

Another strategy which the Christians followed, was to proclaim "the unmediated presence of God to each and every individual and thus the concomitant unmediated presence of each individual to every other individual" (Crossan, 1988:11). Crossan (1988:11) further states that such a proclamation was "radically simple, profoundly paradoxical, religiously provocative and politically explosive". As such, "the proclamation of divine immediacy undercut the very distinction of Jew and Gentile, occupied and occupier, friend and enemy, and therefore had acute political consequences" (Crossan, 1988:12; cf. also Smit, [1993a]:29ff). ${ }^{16}$

These strategies by the Christians did not only do away with imperial strategies of power and control, but also had an immense impact on peasant people. It is in the contest for the allegiance of (at least) the Jewish peasant population that Jesus (and the Christians) came into conflict with the Jewish Pharisees. Since the Pharisees lost their political power in 67 B.C. they deployed a (religio-political) strategy to keep the Jewish population together. In a situation where the temple élite (Sadducees and priests) was either coerced into collaboration with the Roman oppressors or appointed by them (cf. Horsley \& Hanson, 1985:62), the Pharisees extended the purity requirements of the Law for the priests to the local population. Their strategy of keeping the

16 Borg (1984:27) states in this regard that "contemporary circumstances are the medium within which religious movements grow and the conditions to which they must respond, directly or indirectly". Although we can assume that the Christians did not support revolutionary movements which resorted to armed resistance of Imperial hegemony directly, the mere fact of the particular form of their social organization placed them outside the sphere of Imperial control. Indirectly, they did resist Imperial control. Borg (1984:28) argues that:

"Contrary to the picture commonly drawn by scholarship and gencrally accepted until recently, resistance to Rome in first century Palestine was not concentrated within a revolutionary party, whether known as the 'Zealots' or by some other name, but cmbraced people from all segments of the population, cutting across geography, scctarian allcgiances and social classes. 
Jewish nation together in a situation of oppression and coercion with the requirement that all people should live in their own homes according to priestly purity laws was aimed at obtaining the allegiance of the local peasantry. On this level, they came into conflict with Jesus (and the Christians) who also aimed at acquiring the allegiance of the local population. Although these discursive practices were in conflict with one another, they can both be regarded as discursive practices from below (cf. Smit, [1993b]), that reacted against the dominant discourse of imperial control either directly or indirectly. It is also obvious that despite the fact that both the Christians and the Pharisees reacted in their own way to the powers of imperial control, the discourses which they produced had the local peasantry as object of their religious practices. This brought Christians and Pharisees into conflict. 17

\section{THE RULES OF EXCLUSION IN THE MARKAN DISCOURSE: EXTERIOR RULES OF POWER AND DESIRE}

Foucault's (1972:216) model of discourse or rules controlling discourse starts with rules or systems of exclusion functioning on the exterior of discourse. Applied to the Markan discourse, these systems include three types of prohibition, a division between reason and folly (madness) and a division controlling the speaker's (or character's) and reader's (or implied reader's) will to truth or will to knowledge.

\subsection{Three exterior rules of prohibition in Mark}

Since all discourses utilise power, we find rules of exclusion and prohibition also operating in the discourse in a canonical gospel like that of Mark. There are basically three types of prohibition in Mark, viz. the prohibitions concerning objects, prohibitions concerning ritual and the identification of one particular individual (Jesus) who is given the privileged or exclusive right to speak about particular objects or subjects, thereby providing the discourse with a particular content. In Mark, these prohibitions form an intricate web in which they interrelate, support, and supplement each other. Although these three prohibitional strategies are discussed together, the first two basically function as support for the latter.

17 Bammel's (1988:209) study with regard to whether the Christians were regarded as revolutionaries by official Judaism of the time, is informative. He comes to the conclusion that "His (i.e. Jesus) and his followers' revolt against the Torah is presupposed but no attempt is made to shift this to a political level and to denounce the Christians as revolutionaries in the strict sense of the word". 


\subsubsection{The objects of prohibition and ritual}

The objects of prohibition in Mark are those dealing with cultic activities (at the temple and in private life), the social interaction of people, relations with the kin group and by implication, politics.

Where the cultic discourse controlled all human activity through its ritual activities at the temple and the pharisaical discourse propagated halakic rules of purity (against defilement and uncleanness) in order to control the everyday life of the individual, the Markan discourse negates all these by prohibiting its adherents to participate in either the cultic or the halakic rituals and rules. As such, it prohibits the preservation of and adherence to the cultic practices and the purity rules - which not only defined the Jewish religious groups but also ensured the survival of the Jewish people under Roman oppression.

Against the salvific practices of the temple cult, the Markan discourse propagates Jesus to be God's agent of salvation (cf. 2:1-12 \& 14:62-64), thereby prohibiting association with and participation in temple activities. As in numerous other instances of reversal in the Markan discourse, the Pharisees' criticism of Jesus functions on the literal level of interpretation. According to Mark, they regard Jesus' statement on forgiveness as being in conflict with the fact that only God can forgive sins (2:7). This is, however, not the level on which Mark conducts his discourse. The question is not whether Jesus replaces and acts as God - whether the prerogative of salvation moves from God to Jesus. As is clear from Jesus' statement in Mark 2:10, the question is a question of authority - i.e. in whom (or what) is the authority vested to administer the salvation of God. One of the primary aims of the Markan discourse is to prohibit followers of Jesus to participate in temple rituals and rites of salvation. Mark's discourse shows that the authority to administer salvation is vested in Jesus, the "Son of Man" (cf. Smit, [1993c]).

Against the purity rules and educational activities which regulated the social interaction (viz. eating practices) of faithful Jews, the Markan discourse propagates the eating together with the impure - according to dominant 'Jewish' discourse - sinners and tax collectors (2:13-17). The Markan discourse hereby prohibits intimate and educational interaction (such as taking place at meals) in exclusive groups where people's lives are controlled by the halakic rules of purity. The Markan discourse also prohibits the practice of the ritual of fasting. The solemn ritual of fasting which advances physical and spiritual purity should be replaced by celebration and joy (as found at weddings 2:18-22). Against the prohibitions related to the Sabbath (2:23-28 \& 3:1-6), Mark's discourse promotes the view that satisfying human need (hunger) and helping a person in need (healing) take precedence over adherence to Sabbath regulations. As such, the Markan discourse prohibits adherence to Sabbath stipulations and establishes human 
need as the ultimate factor which should control the behaviour of the followers of Jesus. These prohibitions are closely related to the prohibition of followers of Jesus to adhere to the halakic rules of "the Pharisees and the scribes" (7:1-9 \& 14-23) at the expense of humans in need (parents - 7:10-13).

As far as relations with the kin group are concerned, the Markan discourse ruptures the very basic anthropological tenet of Mediterranean society (cf. Malina, 1981:51ff) namely that an individual acquires his/her identity in his/her interaction with the kin group ( $3: 31-35 ; 6: 1-6 ; 10: 28-31)$. Mark's discourse hereby prohibits adherents from allowing relations with the kin group and more particularly the family, to play a more important role than following after Jesus. Since the husband-wife relationship is, however, grounded in creation (cf. Smit [1993a]), the Markan discourse upholds this relationship as ordained by God (10:1-12). In a society in which the cultic and ritual practices served the purposes of either the Jewish nation on the one hand or the interests of authoritative figures (as defined in terms of Jewish and Roman society) on the other, the Markan discourse constitutes practices which are diametrically opposed to those of the governing agencies. The Markan discourse does not only ignore but also negate the strategies which are employed to prohibit unclean, impure and unwanted people 'from outside' from entering and participating in the 'privileges' of the Jewish and Roman societies. As such, the discourse does not only establish a different 'language' but also practices which are at cross purposes with the dominant Jewish and Roman practices. Mark's own strategies of prohibition are all directed at the disarming and suspending of the rules of exclusion and control operating within Judaism and Roman society. His own discourse is aimed at demarcating the boundaries of his own socio-religious group. Through the identification of the objects and rituals in which his own group is not to participate, Mark endeavours to regulate entrance into his group.

Since the rules of prohibition function on the periphery of discourse, we can also identify all the people who are excluded from the discourse as undesirable in terms of the Markan discourse. These include the Pharisees, the Herodians, scribes, the rich man, the Sadducees and the high priest. The fact that Mark puts them uncritically together in one social group is a mistake in terms of traditional historical research. ${ }^{18}$

18 Cf. Scott (1988:173):

"An injustice to the text is committed when the background of Judaism for each conflict passage is conjured as an empty, legalistic, morally deprived faith refusing to hear the truth. A more appropriate interpretation of the texts would understand Judaism as a multifaceted religious phenomenon with many divergent elements."

As Rabbi Hilton and Frier Marshall (1988) have pointed out, many of the pronouncements and activities against these diverse Jewish groups are not exclusively true of 'the Jews'. Torah allows for the same 'transgressions' of the Law which Jesus propagates. This is, however, how Mark pictures 'the Jews' in order to effect a boundary which excludes and 
Numerous scholars have described the pluriformity of Palestinian society and the corruption - brought about by Roman oppression - which existed in those chaotic times. But this is not our main concern here. By placing them all in one socio-religious group, it is obviously Mark's strategy to discredit the whole of 'official' Judaism of his time. His main concern is to point out that all these officials do not perceive or acknowledge the messianic identity of Jesus.

The people who do perceive the messianic identity of Jesus and who are to be part of the Markan group are all those people who can be described as 'marginalized' people in terms of the dominant discourses. These include the demon possessed (who are freed from their demon possession in the process: 1:21ff,39, 5:1ff, 9:14ff), the sick (who are healed: $1: 29 \mathrm{ff}, 40 \mathrm{ff}, 2: 1 \mathrm{ff}, 3: 1 \mathrm{ff}, 5: 21 \mathrm{ff}, 6: 35 \mathrm{ff}, 7: 24 \mathrm{ff}, 8: 22 \mathrm{ff}, 10: 46 \mathrm{ff})$, the sinners (who are forgiven) and the tax-collectors (can we infer: who are liberated from their exploitation of the people? 2:13ff). Jesus is the one who is portrayed as having the final say about who belongs and who does not belong. He himself only associates with people whom the dominant discourses regard as 'marginalized people'. According to the discourse of Jesus, these people belong to the centre of the group of people who are called to live under God's rule. In terms of the dominant discourses, these people are shameful people and cause embarrassment. To the people who belong to the Markan group, they are, however honourable.

The whole web of discursive strategies whereby the Markan discourse endeavoured to control his own group must have had important political consequences. In terms of the dangerous object of politics, we also have to add the (possible) expectations of a political messiah which it seems that Mark totally discredits (8:27ff, 9:2ff, 9:33ff). When James and John request Jesus that they may sit at his right and left hand - i.e. when he becomes the political king - Jesus strongly reprimands them. He equates their request with Gentile rulers who misuse their power. He subsequently states that his followers are not to do as the Gentiles by "lording it over others". He replaces this strategy of the dominant order with the egalitarian principle of service to others (10:35ff). That his own discourse has serious political consequences is - so it seems overlooked by Mark. The statements that Jesus curses the fig tree (11:12ff \& $20 \mathrm{ff})$ - a symbol of the Jewish nation (cf. Telford, 1980) - cleanses the temple of all its economico-political activities (11:15ff), ${ }^{19}$ tells a story about wicked tenants $(12: 1 \mathrm{ff})-$ a

includes.

19 The fact that the story about the cleansing of the temple is preceded and followed by the fig tree story is ample evidence of the Markan strategy to portray Jesus as the authoritative subject who discontinues the Jewish cult. 
reference to the Jewish leadership - and gives an evasive answer as to whether taxes should be paid or not (12:13ff), must have had serious political implications, not only for Jesus himself ${ }^{20}$ in his own situation, but also for the Markan discourse.

\subsubsection{The exclusive right to speak authoritatively}

In the Markan discourse, Jesus has the privileged or exclusive right to say which strategies should be followed with regard to the objects and rituals described above. This strategy of the discourse has a dual purpose. On the one hand it is used to employ the various strategies of prohibition described above, to provide them with a particular content and also with a particular authority. On the other hand, it establishes Jesus as the only authoritative figure in the discourse, and for that matter, all discourses. ${ }^{21}$

On the basis of the fact that the Gospel of Mark functions in South African society as a canonical text which is utilised by churches to regulate and control the behaviour of church members, it is interesting to notice which of the strategies employed by the gospel discourse are continued in South African society and which are not. Except for the husband-wife relationship (which it used only for the purity of white society), apartheid control did not use any of the strategies which affirm the authority of Jesus as it functioned against the cult (ethnicity), the fact that human need takes precedence over any cultic (ethnic) or purity requirement, that all kin group (race) relations are relative to the requirement of following after Jesus and that all people who uphold any strategy which is excluded by the authoritative Jesus discourse are to be excluded from Christian society and discourse or the life under the rule of God. It stands to reason that apartheid cannot in any sense whatsoever be labelled as Christian; also that Christians and even 'non- believers' who acted in accordance with these strategies (with serious political consequences) acted in accordance with the Jesus discourse in Mark.

This is a common phenomenon in high group and high grid (cf. Malina, 1986:29ff) societies - e.g. where exclusion functions with regard to other castes and other classes.

20 Jesus' activities and preaching must have drawn dissident Jewish groups and people who could not align themselves with the establishment, to himself and also into his group. Sigal (1986:5) points out that Jesus' "messianic preaching could not but hearken the Zealots and sicarii and frighten the establishment. The priests could broaden the base of their anti-Jesus conspiracy by appealing to the interests of the perushim (the Pharisees - my insertion) while really being frightened of the messianic fervour exhibited by the Zealots and the sicarii. However, they had no doctrinal basis for putting him to death, and the only way to achieve this was by using Roman authority to suppress potential insurrection".

21 Cf. also references to this authority in $1: 22,27 ; 11: 28 f$. 
All other strategies employed by the Christian apartheid system basically resemble the strategies of the Roman Imperium, the (by Mark misrepresented) corrupt Jewish collaborators and the Jewish halakic scholars. All the rules of prohibition and control in the Markan discourse which aim at the inclusion of people who are marginalized by the dominant discursive practices were negated by the Christian apartheid system. The mere fact that this system followed strategies whereby people were excluded from religious, political, economic and educational discourses and discursive practices on the basis of race or class, exposes it as being at cross purposes with the Markan discourse and the practices propounded by Jesus. Its strategies are diametrically opposed to those of the Markan discourse.

\subsection{The division between reason and folly (madness)}

In the social discourse of Mark, we find that the distinction between reason and folly, madness or demon possession (cf. Foucault, 1967) also functions with regard to Jesus. The fact that Mark reports that Jesus' family wants to stop him from his activities and his teaching because the crowds are saying that "he has gone out of his mind" (3:21) and the "scribes who came from Jerusalem", that "he has Beelzebul" and an "unclean spirit" (3:22 \& 30) indicates that Mark acknowledges that such a description of Jesus is indeed possible. ${ }^{22}$ In accordance with the dominant discourses within Judaism and Roman imperialism, Jesus' strategies with regard to his healings, exorcisms, forgiveness of sins and transgression of socio-religious precepts are regarded as madness and demon possession. 23 This is a powerful strategy which is used to exclude or silence discourse which is not conversant and congruous with the rules and procedures which determine what is healthy, normal or rational. ${ }^{24}$ From the perspective of the dominant

22 The question whether Jesus was 'really' labelled as mad and demon-possessed (in the historical critical sense of the labels) is not important in terms of the study of the materiality of discourse. The description of Jesus as ' $m$ ad' is a literary/ rhetorical strategy in the Markan discourse. As such, it functions together with other strategics (cf. the strategies of 'the messianic secret', 'fear', the 'misunderstandings' and the use of irony) to legitimize the Markan discourse.

23 Whereas modern science describes madness as disease, ancient societies described it as demon possession. In many instances, discase itself was described as demon possession in ancient times.

24 It secms as if the strategy to scgregate or excommunicate the leprous from society was effected by the pronouncement of a priest at the temple that a person was leprous, the fact that such a person should live outside the general social sphere and that s/he should cry out 'unclean' when somebody else approached. If the regulations of Leviticus 13 and 14 were followed in the time of the Markan discourse with regard to the exclusion and the resocialisation of the leper - which is a possibility (cf. Mark 1:44) - the divide which separated the social sphere from the sphere of the leprous was indeed serious. The leprous, the mad and the demon possessed all found themselves in the liminal state of 'being silenced' 
discourses, Jesus does not obey their unspoken 'archive' of rules and constraints. He is therefore labelled as 'out of his mind' and 'demon possessed'. From the perspective of Mark's Jesus discourse, the dominant discourses conjure up this possession or madness in order to evade the moment of anxiety and disturbance, the social (and by definition, political) realities which Jesus represents and which they refuse to confront. Just as with the mad, those with contagious diseases and the demon possessed have traditionally been banished to the margins of the community, to the (non-human) uninhabited places and the country side; Jesus too, is 'forced' to labour in these regions (cf. 1:45). The madness of Jesus and his non-conformity to socio-religious precepts (cf. his transgressions in 2:1-3:5), make him not only unwanted in society, but dangerous (cf. $3: 6$ ). The type of order which the dominant discourses envisage and the principles of social cohesion which their archives allow, are violated by Jesus the madman. The fact that it is not only Jesus as individual which is a threat to the dominant discourses and the order in society but also the fact that large crowds follow him, are clear indications that a dissident discourse and a dissident group of people are forming alongside the dominant discourses.

From the perspective of the Markan Jesus discourse, it is this function of madness where the true is taken for the false and the false for the true - which reveals the identity of Jesus. Beneath the error which the dominant discourses define, Mark reveals the secret enterprise of truth - the messianic identity of Jesus. Mark uses this strategy on the exterior of discourse in order to reveal that the people who label Jesus as mad and even his family (who are by implication part of the dominant discursive practices) do not perceive who Jesus really is and they are therefore excluded from the discourse of the Markan group. Those who perceive his identity in his healings, his exorcisms and his transgressions of precepts, however, follow after him.

This strategy of reversal (where the mad is the true) is probably the most characteristic strategy of the Markan discourse.25 It functions in strategies related to 'secret' (where

- often permanently - and relegated to the domain of non-existence by the dominant discourses. It is this domain of non-cxistence which is called into existence under the rule of God by the Markan Jesus discourse. (Cf. Foucault's study of sexuality (1979) in regard to the silencing and repression of the unwanted.)

25 I agree with Dahl (1983:29) and others that the strategy of reversal is not a literary device which heightens the suspense in the narrative. The revealed or the opposite information is already provided in the text - if not in the immediate literary context, then already in the title of the narrative: "The beginning of the Gospel of Jesus Christ" (1:1). The reader already has the information with which $\mathrm{s} /$ he can fill the gaps created by these reversal stratcgies. In Smit ([1993c]) it is argued that the main function of these devices is to bring about what Jesus sets out to do: repentance and faith $(1: 15)$. It is especially in these gaps that the reader is manipulated not only to supply the missing information, but to convert and belicve. The tension which is created, exists between the reader and the character. The character's not- 
the secret is the revealed), 'fear' (where the feared is the trustworthy), 'misunderstanding' (where the understood is the misunderstood) and irony (where the literal is the incorrect) (cf. Smit, [1993c]). Apart from the fact that these strategies function to bring the reader to conversion and faith, they also function as a strategy of control and exclusion. The mere number of times these various forms of inversion appear in the Markan discourse indicates the intolerance and discursive resistance of the Markan discourse to the hegemony of the other discourses in the society of the time. It also reveals the vehemence with which the Markan discourse negates the opposing discourses and the passion with which it propagates its own discourse. This is pointed out in Smit ([1993c]) that it is precisely in these reversals that the discontinuity of the Markan discourse with the dominant discourses comes to the fore. It is also here, in the breaks, that the reader is seduced into repentance (and a turning away from the dominant discursive practices) and faith (in the Markan Jesus discourse). As such, these (rhetorical) strategies of reversal function as thresholds, ruptures, breaks, mutations and transformations ${ }^{26}$ which force the reader to accept the Markan perspective of Jesus. Needless to say, it is also within these reversals that the 'awesome' materiality i.e. the powers of control and exclusion - of the Markan discourse hides itself. These observations bring us into the domain of the division controlling the speaker's (a character in the story) or reader's will to truth or will to knowledge.

\subsection{The will to truth and the will to knowledge}

The dominant discourses themselves are founded on a will to truth and a will to knowledge. Since the truth and the knowledge of the dominant discourses do not satisfy or provide for the desires of those who are excluded, the Markan discourse is generated to fulfil these desires. In the rejection of the dominant discourses and the generation of a new discourse, a new truth and a new knowledge come into being. In the process of formation, adherents of the new discourse are oblivious of the power of control and exclusion which the new discourse itself harbours (cf. Foucault, 1972:219). In its claims to truth and knowledge and in the adherence to these truths and knowledge in blind faith, its own power of control and exclusion is masked. This power

knowing in the presence of the revealed knowledge - that of the reader - functions as an additional force of the reversal strategy to force the reader into repentance and faith.

26 I endeavour to describe these mutations - in the sense of certain qualities of the opposing discourse which are retained and new qualities which are added to it to form the new discourse - more accurately in Smit [1993c]. 
of exclusion of the Markan Jesus discourse is concentrated in the inversions described above.

Some scholars (cf. Kingsbury, 1989:34) agree that it is "God's point of view" which functions as the "measuring rod" which leads the reader to supply the correct information in the inversions. ${ }^{27}$ It is, however, not only God's view of Jesus (cf. 1:11 \& 9:7) which provides the reader with the correct messianic information but also that of the demons (1:23-25, 34, 3:11f, 5:7ff). It is therefore more correct to say that it is the transcendental or mythical perspective which leads the reader to supply the correct information. By situating the principle of knowledge and truth in the transcendental realm, the Markan discourse makes it impossible for the reader to question the knowledge and truth of the Markan Jesus discourse. To this must be added that Jesus' interpretation of the Law is identified as the normative (and God-willed) interpretation and that the halakic rules of the Jewish representatives are described in terms of human desire (7:1ff). The hegemony of the knowledge of the discourse is clear. In the situation of Roman and Temple oppression and suffering in a society where 'marginalized people' form the largest number of people, the generation of the Markan discourse can be regarded as an important coping strategy. It is the only way out repentance, faith in Jesus the Messiah, behaviour which is modelled on the Prophets' and Jesus' interpretation of the Law 28 and the eschatological hopes of liberation (from suffering and persecution - cf. Mark 13) and vindication (13:24-27 \& 14:62) within Mark's own generation (13:30f).

One can be emotionally stirred by this story of Mark. ${ }^{29}$ One can even excuse its own power of control, exclusion and antagonism towards the (corrupt) Jewish officials of his

27 In his criticism of Booth's four identifying marks of irony, Fish (1989:180ff) argucs that the mere identification of the literal is alrcady an interpretation (informed by the interpretive community). If we depart from this premise, a different interpretation of the strategics of inversion is possible. Such an interpretation is provided in Smit [1993c].

28 In Smit ([1993a]) it is argued that it was primarily the "laws of the Creator-God" which the early Christian communities adhered to. In the disrupted, unstable and insecure society of first century Palcstine (cf. Käsemann, 1977:41ff) the Christians sought stability for themselves as wcll as others who suffercd in this situation through a greater freedom from laws and rcgulations of others and an adherence to a minimum Law - the Law(s) of the CreatorGod.

29 Jameson (1986) describes the stories in which power functions - a power of which the subject is oblivious - socially symbolic acts in which the 'political unconscious' harbours itself. The rcason why the political power of these stories are not consciously expressed is to be found in the unconscious, collective desire for the resolution of social contradictions and the establishing of social unity. 
time. The story, however, changes dramatically when it is used uncritically in a context where it aligns itself with state power. Sheridan (1980:119) states that the historical analysis of the antagonistic and vindictive will to knowledge rests upon injustice and that the instinct for knowledge is malicious - something murderous. Although the early Christian discourse constituted discursive practices from below which reacted against Jewish and Imperial discourses of oppression, in time (and for that matter throughout the centuries), when Christianity found itself in an alliance with state power, the materiality of the Christian discourse had devastating consequences for other people. After 312/313 C.E. and 324 C.E., when Christianity gained recognition by the state and became part of state power, the situation changed radically. Christianity did not find itself in the political domain of the reactive coping discourse of the persecuted and oppressed any longer, but in the political domain of the active discourse of the ruler, persecutor and oppressor. The horrors of this mutation of Christian discourse is amply illustrated in the oppression of Jewish people throughout the centuries - which culminated in the Hitlerian 'Final Solution' and Holocaust (cf. Weinreich, 1946 \& Wistrich, 1985) - and various redefinitions of the opposition to a Christian world view, morals and values (e.g. the apartheid view that other races constitute a danger to Christian values).

It is my belief that it is the uncritical use of a canonical writing (among other strategies) like that of Mark which informs activities which are diametrically opposed to the good news message of love, service and unconditional acceptance of other people which is a trademark of the gospel. The disturbing factor is that Christians find the legitimation of their institutional control and oppression of Jews and other ethnic groups and classes in their canonic writings.

I have already shown that the reversal strategy is a major strategy of the Markan discourse. Its power of control, however, does not only function to bring people into an acceptance of Jesus as Messiah. The materiality of the language used also has an opposite effect. The most significant is that if Jesus is not a demon, then the Jews are the demons (3:22-30)..$^{30}$ To this can be added all the other derogatory references to temple representatives in the Markan discourse (e.g. 3:6 and 7:1ff. among others) and the controversy or conflict discourses between Jesus and the temple representatives. The argument is that these conflicts and references could have had some truth in them

30 Trachtenberg (1983) traces the development and hegemony of this idea from medieval times to modern anti-Semitism. He provides a comprehensive overview of the function of this phenomenon in art, legend and Christian discourse. Although it is possible that the Markan text has not been used explicitly in the description of 'the Jews' as demons, its cover materiality allowed such descriptions and legends - with devastating consequences for Jews. 
at the time of Jesus and especially that of Mark, ${ }^{31}$ but to reactivate them in all their materiality from society to society is a hermeneutical and heuristic mistake which has cost Christianity dearly. Christians cannot afford to be oblivious of their 'uptake' of these strategies.

The divisions of the will to truth are reliant upon institutional support and distribution. They aim at exposing opposing discourses and in this activity, cannot but mask themselves. It was in a situation where the dominant discourses did not cater for the desires of the peasant people that this new mutation of discourse based on the Jesus event and the classic Jewish writings, originated. I have shown that the materiality of the strategies which Mark employed forces one not to repeat them in all their materiality in present discourses - as it was done by the technologies of the total onslaught of apartheid.

It is important that I mention one last example. Possibly the most awesome demand of the Markan discourse on those who have the right knowledge of Jesus as Messiah, is to follow Jesus and to be willing to suffer and die on the cross. This is the ultimate strategy of exclusion. It is the point at which those who follow after Jesus and those who do not follow are separated. Without going into the interpretation of this text, but just taking its materiality into consideration, it is important to note that this text and similar ones in the New Testament, demands the sacrifice of oneself, a sacrifice which has led in the history of gospel discourse to the most dreadful self-denials, psychological disturbances and even self-seeking martyrdoms. Where 8:34ff. is reactivated in all its materiality, e.g. to demand of people who are already oppressed to submit to this charge, the (fully masked) power of the Markan discourse comes to the fore. If this demand functions as a strategy in the community of the oppressed, the rootless and the exploited - as in Roman society - it can be viewed as an ultimate (though tragic) example of the resistance of the powerless. However, if it is not practised by the Christian dominant discourses themselves, but demanded by them, it functions as the ultimate strategy of oppression, the ultimate dissolving of ties with the Markan Jesus discourse.

31 Sandmcl (1978:48) rightly argues that Mark (at least on the surface of discourse) differs from Matthew and Luke in so far as Christianity is portrayed as only having "negative connections with the Judaism into which it had been born". 


\section{CONCLUSION}

No discourse is innocent. 32

I believe we must accept three decisions which our current thinking rather tends to resist in the canonical reading and interpretation of the Bible: to question our will to truth fundamentally in terms of exposing its materiality - as it realizes itself in sermons, Christian and theological books/articles and especially in commentaries; to restore to discourse its character as an event - thereby exposing and unmasking the power, the manipulation and the strategies of control employed by our canonical biblical writings and ourselves and finally to abolish the sovereignty of the signifier, i.e. the canonical text. ${ }^{33}$ But this is a different history.

And if I may say finally, like Foucault (1972:215), rather than be him from whom "discourse proceeds", I also, especially in the South African context and the religious hegemony playing havoc with people and peoples' lives, would prefer to be a "slender gap" in discourse, "the point of its possible disappearance".

\section{BIBLIOGRAPIHY}

BAMMEL, E. 1988. Jesus as a Political Agent in a Version of the Josippon. (In Bammel, E. \& Moule, C.F.D., eds. Jesus and the Politics of His Day. Cambridge : Cambridge University. p. 197 209.)

BIALE, D. 1986. Power and Powcrlessness in Jewish History. New York : Schocken.

BICKERMAN, E. 1988. The Jews in the Greek Age. Cambridge: Harvard University.

BORG, M. 1984. Jesus: Conflict, Holiness and Politics. San Francisco : Edwin Mellen.

CROSSAN, J.D. 1988. Materials and Methods in Historical Jesus Rescarch. Foundarions and Facets Fonum, 4(4):3-24

DAHL, N.A. 1983. The Purpose of Mark's (jospel. (In Tuckelt, C., ed. The Messianic Secret. Philadelphia : Fortress. p. 29-34.)

DREYFUSS, H. \& Rabinow, P. 1982. Michel Foucault: Bcyond Structuralism and Hermencutics. With an Afterword by Michel Foucault. Sussex : Harvester.

FEARS, J. 1980. Rome: The Ideology of Imperial Power. Thought, 55(216):98-108.

32 Since all forms of discourse exert their powers of control and rarefaction on the subject and arc by definition negative, Foucault does not want to make a distinction between more and less acceptable forms of power and control. In the final analysis, he does, however, concede that if the basic hypothesis that all discourses exert power on the subject is accepted, onc can make the distinction between a negative and positive use of power (Foucault, 1980a:119).

33 Most probably, the abolishing of the sovereignty of the significr - the hegemony of the Bible as text - is not far removed from what Martin Luther meant when he argued that the Bible should never be regarded as a 'paper popc'. 
FERGUSON, E. 1987. Backgrounds of Early Christianity. Grand Rapids : Eerdmans.

FISH, S. 1989. Doing What Comes Naturally. Change, Rhetoric, and the Practice of Theory in Literary and Legal Studies. Oxford : Clarendon.

FOUCAULT, M. 1967. Madness and Civilization. A History of Insanity in the Age of Reason. London : Tavistock.

FOUCAULT, M. 1972. The Archacology of Knowledge and the Discourse on Language. New York : Pantheon.

FOUCAULT, M. 1979. The History of Sexuality. Volume 1: An Introduction. London : Penguin.

FOUCAULT, M. 1980a. Truth and Power. (In Gordon, C. ed. Power/Knowledge: Selected Interviews \& Other Writings 1972-1977 by Michel Foucault. New York : Pantheon. p. 109-133.)

FOUCAULT, M. 1980b. Power and Strategies. (In Gordon, C. ed. Power/Knowledge: Selected Interviews \& Other Writings 1972-1977 by Michel Foucault. New York : Pantheon. p. 134-145.)

FREYNE, S. 1989. The World of the New Testament. Wilmington : Michael Glazier.

HAENCHEN, E. 1977. Dic Apostelgeschichte. Göttingen : Vandenhoeck \& Ruprecht.

HILTON, M. \& MARSHALL, G. 1988. The Gospels and Rabbinic Judaism. A Study Guide. London : SCM

HOFTIJZER, J. 1968. Religio Aramaica. Godsdienstige Verschijnselen in Aramese Tcksten. Leiden : Ex Oriente Lux.

HORSLEY, R. \& HANSON, J. 1985. Bandits, Prophets and Messiahs. Popular Movements in the Time of Jesus. San Francisco: Harper \& Row.

JAMESON, F. 1986. The Political Unconscious. Narrative as a Socially Symbolic Act. New York : Cornell University.

JOHNSON, L.T. 1986. The Writings of the New Testament. An Interpretation. Philadelphia : Fortress.

JOSEPHUS, F. 1982. The Antiquities of the Jews. (In Whiston, W. trans. The Works of Josephus. Complete and unabridged. Lynn : Hendrickson. p. 22-426.)

JOSEPHUS, F. 1982. The Wars of the Jews. (In Whiston, W. trans. The Works of Josephus. Complete and unabridged. Lynn: Hendrickson. p. 427-605.)

KÄSEMANN, E. 1977. Jesus Means Freedom. Philadelphia : Fortress.

KINGSBURY, J.D. 1989. Conflict in Mark. Jesus, Authorities, Disciples. Minneapolis : Fortress.

MACCOBY, H. 1973. Revolution in Judaea. Jesus and the Jewish Resistance. London : Ocean.

MACK, B. 1988. Mark and Christian Origins. A Myth of Innocence. Philadelphia : Fortress.

MALINA, B. 1981. The New Testament World. Insights from Cultural Anthropology. John Knox : Louisville.

MALINA, B. 1986. Origins and Cultural Anthropology. Practical Models for Biblical Interpretation. Atlanta : John Knox.

MYERS, C. 1990 . Binding the Strong Man. A Political Reading of Mark's Story of Jesus. Maryknoll : Orbis.

SANDMEL, S. 1978. Anti-Semitism in the New Testament? Philadelphia : Fortress.

SCOTT, R. 1988. Jesus and the Sabbath: An Investigation of the Sabbath in Jewish Literature from 200 $B C$ to $A D 100$ and Its Impact on the Ministry of Jesus. Sheffield : JSOT

SHERIDAN, A. 1980. Michel Foucault: The Will to Truth. London: Tavistock.

SIGAL, P. 1986. The Halakhah of Jesus of Nazareth According to the Gospel of Matthew. New York : University Press of America.

SMIT, JA. [1993a). The Liberating Justice of the Creator's Laws. (In Balia, D ed. Mission and Theology in South Africa. San Francisco : Edwin Mellen.) (Forthcoming.)

SMIT, J.A. [1993b]. The Perspective from below as the Dominant Hermeneutical Perspective in the New Testament. (To be published.)

SMIT, J.A. [1993c]. Jesus and Judaism in the Gospel of Mark. (To be published.)

TELFORD, W.R. 1980. The Barren Temple and the Withered Tree. A Redaction-Critical Analysis of the Cursing of the Fig-Tree Pericope in Mark's Gospel and its Relation to the Cleansing of the Temple Tradition. Sheffield : JSOT. 
TRACHTENBERG, J. 1983. The Devil and the Jews. The Medieval Conception of the Jew and Its Relation to Modern Anti-Semitism. Philadelphia : Jewish Publication Society.

WEINREICH, M. 1946. Hitler's Professors. The Part of Scholarship in Germany's Crimes against the Jewish People. New York : Yiddish Scientific Institute.

WISTRICH, R. 1985. Hitler's Apocalypse. Jews and the Nazi Legacy. London : Weinfeld \& Nicholson.

WENGST, K. 1987. Pax Romana and the Peace of Jesus Christ. London : SCM 
